\title{
Botanical Knowledge in the Law Enforcement: a Preliminary Approach Towards its Potential Use in Brazilian Criminal Caseworks
}

\author{
Vinicius Manvailer ${ }^{1}$, Thales D. Leandro ${ }^{2 *}$, Edna Scremin-Dias ${ }^{1}$ \\ ${ }^{1}$ Universidade Federal de Mato Grosso do Sul, Campo Grande, Mato Grosso do Sul, Brazil; ${ }^{2}$ Universidade Estadual \\ Paulista-UNESP, - Campus de Rio Claro, Rio Claro, São Paulo, Brazil.
}

\begin{abstract}
We surveyed Brazilian forensic institutes in order to provide a baseline for botanical knowledge used in forensic applications. Our approach provides a better understanding of the law enforcement dynamics as a whole, and establishes perspectives and guidelines for implementing this discipline in Brazil, enhancing the elucidative power of Brazilian forensic institutes.
\end{abstract}

Keywords: Botany, Criminal Investigation, Criminalistics, Forensic Sciences, Plant Sciences.

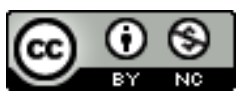

\footnotetext{
* Author for correspondence: v.manvailer@gmail.com; thaleshdias@gmail.com
} 
Recognizing useful botanical traces in crime scenes is crucial for their utility in criminal investigations, as well as to their proper collection and preservation ${ }^{1}$. Relevant evidence may arise from a simple interpretation of botanical traces found at the crime scenes, which often do not require high-cost procedures (e.g., molecular analyses) in the course of the investigation. Although this may be true, the presence of an investigator or a forensic expert with botanical skills is rare in the Brazilian law enforcement, making this approach poorly used, and the botanical traces mostly depreciated ${ }^{2}$.

Botanical traces in forensic caseworks have shown to be relevant if not crucial to the elucidation of many questions related to the dynamics and authorship of criminal events ${ }^{3-}$ ${ }^{9}$. Estimation of post-mortem intervals ${ }^{10,11}$, association between suspects and crime scenes ${ }^{4,12}$, and the discovering of clandestine graves ${ }^{13}$, are some of the classical examples that can be easily addressed. Under those circumstances, Forensic Botany has gained increasing attention within the forensic scenario, resulting in a great number of reports in the literature $2,4,9,14,15$.

Brazil currently comprises 342 forensic institutes in 27 federation units, where each capital has one institute, except for the States of São Paulo and Rio de Janeiro that include 27 and two forensic units, respectively ${ }^{16}$. Although there is a high number of forensic institutes in the country, their infrastructure are often lagged and still remains less valued ${ }^{16}$. Forensic experts thus usually do not have access to many equipment required for basic laboratory tests, often resulting in inconclusive reports and low rates of solved cases.

This work aimed to provide a preliminary panorama of Forensic Botany and its importance to the criminal investigation in Brazil. We explore the topic of techniques for preservation of botanical traces, and also the perspectives to spread this knowledge within the Brazilian Forensic Science in order to improve criminal investigations.

A study was carried out by a volunteer sampling from the professional staffing of forensic institutes in all states of Brazil. This work had quali-quantitative data as the main source, which was obtained based on the botanical knowledge and experience from forensic experts. The methodology herein applied was entirely based on the description given by the work "Diagnóstico da Perícia Criminal no Brasil" (Diagnosis of the Criminal Expertise in Brazil - free translation) developed by the Secretaria Nacional de Segurança Pública - SENASP (National Secretary of Public Safety-free translation) ${ }^{16}$. The concepts found in the SENASP work were the base for building the questionnaires applied to forensic experts.

The questionnaire (available upon request to the first author) was organized in two parts: (1) a general part, equally applied to all forensic experts; and (2) a specific part, applied according to the expert's specialty. The classification used in the specific part of the questionnaire was based on the specialties described in the SENASP work ${ }^{16}$. Specialties of interest were chosen taking into account those that potentially deals with botanical traces in their analyses: Crime Scene Processing (CSP), Toxicology, and DNA. The questionnaire evaluated aspects with regard to: (1) experience with traces from botanical nature; (2) familiarity with sub disciplines of Botany (e.g., systematics, morphology, palynology, etc.); (3) notions about the necessary infrastructure for the collection, preservation, and analysis of plant traces; and (4) usefulness of Botany in the forensic context of their specialty. At the end, an expert opinion with regard to the importance of Botany as a discipline for forensic analysis was requested.

The knowledge with respect to the proper collection and preservation of botanical traces was evaluated according to the methods described by Hall and Byrd ${ }^{1}$. In their work, methods for processing botanical material were standardized taking into account different aspects of an investigation, from the importance of the chain of custody in the collection 
procedure to the presentation in court. Since the specialties performed by the experts vary according to the organizational structure of each Brazilian state, and one or more specialties are often performed by the same forensic expert, in the second part of the questionnaire was required the selection of the specialty with higher demand in their work routine. This set up had the purpose to better orientate their answers and our results, avoiding any misinterpretation in fulfilling the questionnaire.

In order to reach forensic experts that perform at least one of the three above mentioned specialties, directors of forensic institutes were interviewed for better understanding how the specialties described in the SENASP work were distributed among their departments. In the State of Mato Grosso do Sul, for instance, more than one department could be classified as external processing due to the nature of their analyses of routine. The questionnaire was made available via Google Drive and also on the National Forum of Criminal Experts website.

Although all the 27 Brazilian federation units have been consulted, we have obtained responses from 15 of them (Fig. 1). The forensic institute of the State of Ceará was the only unit that have declared not to perform Forensic Botany analyses. The most participative specialty in this survey was Crime Scene Processing (CSP), followed by DNA, and Toxicology. The CSP specialty (or commonly referred to as "external processing" in the Brazilian forensic institutes) is the specialty that comprises most of the experts in Brazil. This specialty is one of the most important in obtaining botanical evidence in forensic caseworks, and it is responsible for the collection, preservation, and forwarding of the evidence to laboratories for proper analysis 18 - the remainder of the specialties are therefore dependent to the correct operation of the CSP. It is worth mentioning that the low feedback of DNA and Toxicology did not allow to obtain a panorama for these specialties. The analyzed responses of these specialties were thus obtained only from the general section of the questionnaire and from the expert opinion survey. 


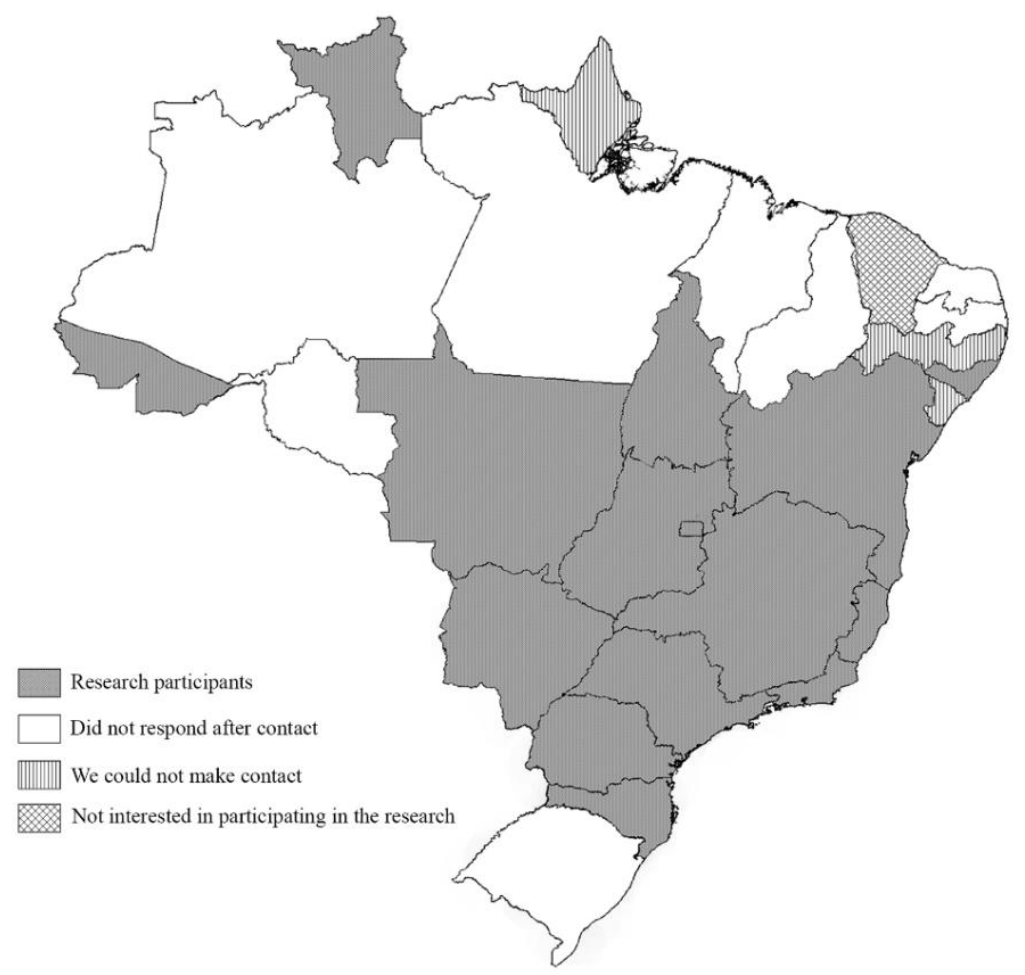

Figure 1. Federal units of Brazil participants and non-participants of the research.

With regard to the experience of the forensic experts with plant traces and their familiarity with sub disciplines of Botany, there were remarkable results considering the reality of the Brazilian forensics. From the total of experts interviewed (35), 39\% already had contact with or have knowledge about plant traces being a useful evidence in environmental crimes, crimes against person and/or drug traffic. This result reinforces the importance of including botanical evidence in forensic investigations ${ }^{17,18}$, as well as suggests a demand for the inclusion of this type of evidence in Brazilian forensic reports.

As to the familiarity with Botany, $60 \%$ of the forensic experts recognize at least one of the sub disciplines and $36 \%$ recognize three or more. The sub discipline most cited was plant morphology (40\%), probably because it is one of the most traditional topic of study in Botany and the one with easiest access to literature. Familiarity with Botany is really important and allows forensic experts to explore most suitable analyses according to the specific casework in which the evidence was found ${ }^{14,15,17}$; and thus it constitutes one of the first steps in how the evidence will be interpreted. The better is the ability of an expert to recognize and distinguish among the disciplines of Botany, the better is your ability to build proper knowledge and interpret botanical evidence correctly.

Forensic experts of the CSP specialty (26) were questioned about their familiarity with methods of collection and preservation of botanical materials. Subsequently, we offered a hypothetical situation in which plant organs were found at a crime scene and asked them to select the best method to preserve each plant organs listed (e.g., alcohol $70 \%$ for root, silica for seed, and plant press for flower). A key factor in interpreting botanical evidence usually is to properly identify the plant or plant fragment in question. A correct taxonomic identification provides means to acquire useful information with regard to plant biology and ecology, which in turn may lead to the confirmed association between crime elements. Although $21 \%$ of the experts claimed to know about the proper methods of collection and 
preservation, their responses with regard to the best method for each organ varied considerably. (Fig. 2 A). A greater tendency was verified for methods that utilize paper bag and plant press, regardless of plant organ in question (Fig. 2A). It is worth mentioning that none of the forensic experts that claimed to know the proper collection and preservation method chose for the plastic bag method-probably due to the understanding that plastic bags favor the proliferation of fungi and/or bacteria, and thus may compromise trace evidence integrity 1. As for the forensic experts that do not know the proper collection and preservation methods, there was also a greater tendency to for them to choose the paper bag and plant press methods, but their responses were considerably variable (Fig. 2 B). In general, one can notice the good notions about both collection and preservation methods of plant trace; however, considering that there are great divergences in the responses, the utilization of techniques by some forensic experts places a risk to the trace integrity. Since paper bags are constituted of porous material that would provide aeration to the plant trace, we suggest the utilization of this method as an appropriate alternative instead of the conventional plant press method. One may argue that the proper method for preservation and/or preparation of a given botanical trace depends on the nature of the sample and the type of analysis - e.g., for plant anatomy analyses, it is common the use of FAA - Formaldehyde Acid Acetic and Alcohol -, or BNF - Buffered Neutral Formalin. Although this may be true, FAA and BNF are considered for special analyses which should be carried out primarily by a trained botanist or plant anatomist. Hence, as a general protocol for Brazilian law enforcement agents, there is no better way to preserve botanical traces than to dry the material properly.

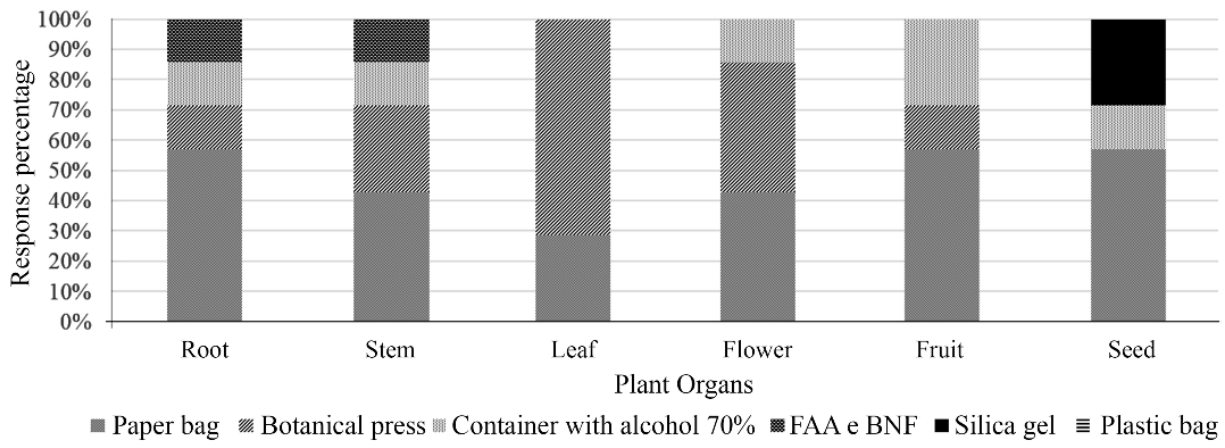

(A)

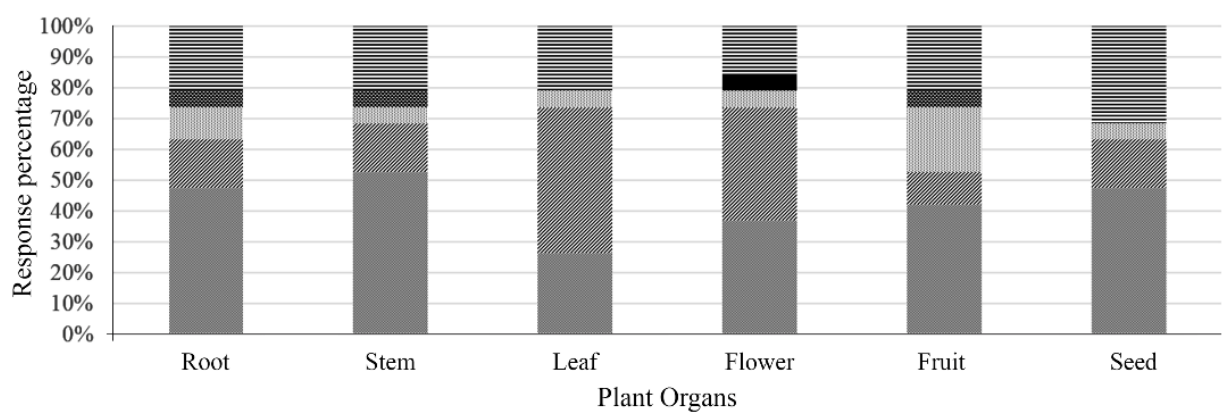


Figure 2. Representativeness of methods of collection and preservation of botanical material with respect to each plant organ. (a) Forensic experts that claimed to know the proper collection and preservation methods. (b) Forensic experts that claimed to not know the collection and preservation methods.

With respect to the necessary infrastructure for processing botanical evidence, only a few Brazilian states declared to have the basic materials and equipment for this purpose-with the exception of alcohol. This scenario was expected considering the general infrastructure listed in the SENASP work ${ }^{16}$, which quantifies the main equipment used in the Brazilian forensic units. According to SENASP ${ }^{16}$, there is a lack of general forensic equipment, and most of the institutes do not have knowledge about their budget. For processing botanical evidence, few equipment are required: (1) plant press for collection of material at a crime scene; (2) incubator for appropriately drying the material; or FAA, BNF, and alcohol for histological analyses; and (3) silica gel for DNA preservation. A forensic laboratory that has all these materials will certainly be able to carry most of the botanical analyses when needed. A trained botanist may be required for certain analyses, but in the same way, employing the correct method of preservation and evidence processing are essential for getting better results in the casework.

In Brazil, there is no hierarchy among evidence, being arranged in the Brazilian Penal Code that "o Juiz formará sua convicção pela livre apreciação da prova" (the Judge will form his conviction based on free evaluation of the evidence-free translation) ${ }^{19}$. Nevertheless, during the investigation and processing of the crime scene, lies with the forensic expert the judgment of whether a trace is relevant to the casework. The expert's judgment is based on the observation of all the elements in a crime scene, aiming to establish its dynamics under the light of the hypothetico-deductive method ${ }^{20,21}$. The hypothetico-deductive method aims to link two or more elements in a crime scene (e.g., weapon of a crime to a suspect), or to aid in time-interval estimations (e.g., to elucidate when a crime has occurred or the post-mortem interval of a victim) ${ }^{13}$. Several cases reported in the literature indicate how Botany may aid in the elucidation of crime dynamics $^{4,5,9,11,15}$, and thus demonstrate their relevance in driving a criminal investigation into the right path. The potential of using plants as an evidence was recognized by almost all the forensic experts in this research, since in sum more than $90 \%$ of them consider very important or important the collection of plant traces in crime scenes. However, only $30 \%$ of them have actually had some experience in the subject. One may argue that, if almost all of the interviewed experts judge the collection of botanical traces to be important, why only $30 \%$ of them reported experiences in the subject? We believe that the answer may rely on their abilities to process, analyze, and interpret these traces properly. As shown here and in the SENASP work, there is a lack of necessary equipment for botanical trace processing and a bit or no training to analyze and interpret such evidences. Thus, although the relevance of a given trace may be subjected to interpretation, we assume this result as the likelihood of a forensic expert to use botanical traces in their investigations if basic conditions for such are met.

With respect to time interval estimations and the association of pollen grains to crime scenes, according to our results, $73 \%$ of the forensic experts consider pollen grains as a potential associative trace and around $50 \%$ of them believe in the possibility of establishing time interval based on botanical knowledge. The fact that $73 \%$ of them consider pollen grains as a potential associative trace to crime scenes is important to highlight, since none of the experts indicated to know the sub discipline of palynology. Giovanelli and Garrido ${ }^{21}$ discuss the practice quality of the forensic institutes; in their work, it is highlighted the lack of a methodological standardization in Brazilian forensic 
institutes, and the inappropriate and subjective means of acquiring scientific knowledge. In Brazil, the scientific knowledge related to forensic applications is really scarce. Forensic experts are not actively inserted in the scientific community and vice-versa, thus the knowledge is usually transmitted verbally and without effective dissemination of the practices and scientific fundaments ${ }^{21}$. An agreement between the Federal Police of Brazil and the CAPES agency - one the main Brazilian institutions related to the improvement of higher education and research - was the first step in getting a different scenario ${ }^{22}$. Considering that the access to scientific journals is very unusual inside the Institutes, it is likely that notions about the subject have been transmitted without great discussions and by a restricted group with access to the subject. Another way to aggregate knowledge is by attending meetings and seminars, however, it usually builds only notions but not an effective and consolidated knowledge about the subject and its real casework application. We believe thus that although the forensic expert may understand the potential of analyzing pollen grains, they are not familiar with the term "palynology".

Post-mortem intervals and other time windows have been reported in books and several case studies ${ }^{1,11,23-25}$, nevertheless, to a layman in Botany, these analyses may prove complicated and usually require a much deeper knowledge. A few ideas were developed by the forensic experts in this research, of which most of them converge to what is found in the literature-germination period of seeds, and the relationship between pollen grain and flowering period of species, for instance. Estimation of time interval and association between elements of a crime scene may be crucial to the development of an investigation. In this context, Botany may provide relevant information about a casework, mainly when conventional methods for determining a post-mortem interval and the association between elements of a crime scene are not applicable ${ }^{15,17,26,27}$. Improving the knowledge of forensic experts to use these resources is an important step to consolidate Forensic Botany in real caseworks in Brazil.

In the last section of the questionnaire it was asked to the forensic experts their opinion with regard to the usefulness of Botany - also considering their specialty in the forensic institutes. This question was meant to be general in nature to give them an opportunity to freely pose their ideas on the subject. About $69 \%$ of them developed ideas about the matter, which provided us a close contact with the reality that they have experienced. Some forensic experts reported poor infrastructures, as well as the lack of human resources and consequent work overload. On the other hand, they also demonstrated a great notion about the effectiveness and applicability of the Botany knowledge in criminal caseworks, and some even showed some excitement with the development of this discipline for the improvement of forensic sciences in Brazil.

The potential for Forensic Botany to be immediately implemented in the Brazilian Forensics scenario is certain. Among the Brazilian criminal caseworks that highlight such perspective is the Mércia Nakashima case and the more recent drowning case in Porto Alegre, State of Rio Grande do Sul. In the first case, algae collected from the suspect's boots was analyzed by a botanist who was able to determine the suspect's presence at the crime scene ${ }^{28}$; whereas, in the second case, the investigators used diatoms retrieved from the victms's lung to confirm location and cause of death ${ }^{28}$. It is also worth mentioning in the context of Brazilian forensic sciences the use and development of novel techniques such as the machine vision for pollen identification ${ }^{30}$. All these examples reinforce the value of botanical evidence in solving Brazilian criminal caseworks. Lastly, with the political movements of the Brazilian Forensics aiming to become an independent organ of public safety ${ }^{31}$, as well as the increase in number of case studies and specific literatures ${ }^{1,9,32-36}$, lies a great opportunity to include the topic in the police academy. The segregation 
of the Forensic Science (forensic scientists) from higher Brazilian organs of public safety at a constitutional level brings advantages, such as the management of forensic units by career professionals - which are the most suitable professionals in understanding the actual demand of the organs. The present moment becomes thus highly favorable to include Forensic Botany as an active discipline in Brazilian forensic science.

At the end of this preliminary survey about the botanical knowledge in the Brazilian law enforcement, some findings and suggestions are noteworthy:

I. Although the perspective is very optimistic, the low feedback denotes the expert's distance with the scientific community as well as with the improvements of current methodological standards;

II. One can notice that the infrastructure that the experts have to perform their job considerably limits the development of new methods and, above all, the quality of forensic reports;

III. Considering the Brazilian forensics limitations, Forensic Botany can aid in criminal investigations with simple and inexpensive methods. Such methods are currently demonstrated by several applications, ensuring their greater efficiency and expansion as a branch of knowledge of the Forensic Science;

IV. Training of experts, mainly the CSP specialty, is indispensable to the development of Forensic Botany in Brazil. Important actions to achieve this should be incorporated, such as the inclusion of the topic in the police academy and incentives to training courses and scientific meetings;

V. Governmental practices that support and encourage the academic insertion in the forensic expert training are essential to build awareness towards the forensic science development as a whole. Such training must be accompanied by investments in infrastructure and equipment that allow the performance of analyses in the forensic unit, ensuring thus the preservation of the chain of custody.

\section{STATEMENT}

With respect to sampling effort, we made several attempts to contact directors and, oftentimes, forensic expert themselves, using both phone and email contacts. The Coordenadoria Geral de Perícias from the State of Mato Grosso do Sul also performed some campaigns to promote the questionnaires, but still without any feedback. This research, however, depends mainly on volunteer action of forensic experts to contribute with information on the subject. Among the difficulties found we include: directors that were frequently busy when we attempted contact, questionnaires that were not forwarded by the directors to the forensic experts, or even the forensic experts themselves, with the questionnaire in hand, did not answered it. Many are the possible reasons for which an institute did not participate in this research. To preserve the objectiveness of the work, we focused thus on the botanical knowledge of the forensic experts that have participated in this research. We believe that whatever was the reason for the low feedback, they have little value for this work. On the other hand, we found important to demonstrate our sampling effort, that is, which units we could actually contact. Moreover, the process itself of understanding the reasons of the lack of feedback would demand the institutes to answer back to us, which would make the process redundant and impracticable. 


\section{ACKNOWLEDGEMENTS}

We thank the Coordenadoria Geral de Perícias of the State of Mato Grosso do Sul (CGPMS) for the support given throughout the development of this study. We also thank the superintendents of the forensic institutes of Brazil for delivering the questionnaires to forensic experts and for the useful information provided.

The authors are grateful to C.R.D. Filho for helping spread the questionnaires and make them available on the National Forum of Criminal Experts website.

\section{REFERENCES}

1. Hall DW, Byrd JH. Forensic Botany: A Pratical Guide. Chichester, UK: John Wiley \& Sons, Ltd, 2012.

2. Coyle HM, Lee C, Lin W, et al. Forensic Botany: using plant evidence to aid in forensic death investigation. Croat Med J 2005; 46: 606-612.

3. Dayanandan P, Kaufman PB. Trichomes of Cannabis sativa L. (Cannabaceae). Am J Bot 1976; 63: 578-591.

4. $\quad$ Graham S. Anatomy of the Lindbergh kidnapping. J Forensic Sci 1997; 42: 368-377.

5. Dilcher DL. Forensic Botany: case studies in the use of plant anatomy. Phytomorphology $2001 ; 181-184$.

6. Acs P, Wilhalm T, Oeggl K. Remains of grasses found with the Neolithic Iceman "Ötzi". Veg Hist Archaeobot 2005; 14: 198-206.

7. Ward J, Peakall R, Gilmore SR, et al. A molecular identification system for grasses: a novel technology for forensic botany. Forensic Sci Int 2005; 152: 121-131.

8. Virtanen V, Korpelainen H, Kostamo K. Forensic botany: usability of bryophyte material in forensic studies. Forensic Sci Int 2007; 172: 161-163.

9. Aquila I, Ausania F, Di Nunzio C, et al. The role of forensic botany in crime scene investigation: case report and review of literature. J Forensic Sci 2014; 59: 820-824.

10. Balouet J-C, Oudijk G, Petrisor L, et al. Emerging forensic techniques. In: Murphy BL, Morrison RD (eds) Introduction to Environmental Forensic. Academic Press, 2007, pp. 671-731.

11. Cardoso HF V, Santos A, Dias R, et al. Establishing a minimum postmortem interval of human remains in an advanced state of skeletonization using the growth rate of bryophytes and plant roots. Int J Legal Med 2010; 124: 451-456.

12. Agashe SN, Caulton E. Forensic Palynology. In: Agashe SN, Caulton E (eds) Pollen and Spores: Applications with Special Emphasis on Aerobiology and Allergy. Enfield, NH: Science Publishers, 2009, pp. 337-345.

13. Wiltshire PEJ. Forensic Ecology, Botany, and Palynology: some aspects of their role in criminal investigation. In: Ritz K, Dawson L, Miller D (eds) Criminal and Environmental Soil Forensics. Dordrecht: Springer Science + Business Media B.V, 2009, pp. 129-149.

14. Coyle HM, Ladd C, Palmbach T, et al. The Green Revolution: Botanical Contributions to Forensics and Drug Enforcement. Croat Med J 2001; 42: 340-345.

15. Bull PA, Parker A, Morgan RM. The forensic analysis of soils and sediment taken from the cast of a footprint. Forensic Sci Int 2006; 162: 6-12.

16. SENASP. Diagnóstico da Perícia Criminal no Brasil. Brasília, DF, 2012.

17. Brown AG. The use of forensic botany and geology in war crimes investigations in NE Bosnia. Forensic Sci Int 2006; 163: 204-210.

18. Rodrigues V, Truzzi S, Gerais M, et al. Perícia criminal: uma abordagem de serviços. Gestão e Produção 2010; 17: 843-857.

19. BRASIL. Código do Processo Penal. Available from: http://www.planalto.gov.br/ccivil/decreto-lei/del3689.htm, 1941.

20. Osterburg JW. Police Science: what problems must criminalistics solve. J Crim Law Criminol Police Sci 1968; 59: 427-433. 
21. Giovanelli A, Garrido RG. A Perícia Criminal com instância legitimadora de práticas policiais. Rev do Laboratório Estud da Violência da UNESP/Marília 2011; 7: 5-24.

22. CCS/CAPES. 2018. Polícia Federal Assina Termo Para Acesso Ao Portal de Periódicos CAPES. Available from: http://www.capes.gov.br/sala-de-imprensa/noticias/8997-policia-federalassina-termo-para-acesso-ao-portal-de-periodicos-capes

23. Quatrehomme G, Lacoste A, Bailet P, et al. Contribution of microscopic plant anatomy to postmortem bone dating. J Forensic Sci 1997; 42: 140-3.

24. Coyle HM. Forensic Botany: Principles and Applications To Criminal Casework. Boca Raton, FL: CRC Press LLC, 2005.

25. Montali E, Mercuri AM, Grandi GT, et al. Towards a 'crime pollen calendar' - pollen analysis on corpses throughout one year. Forensic Sci Int 2006; 163: 211-23.

26. Hall DW. Forensic Botany. In: Haglund WD, Sorg MH (eds) Forensic Taphonomy: The Postmortem Fate of Human Remains. CRC Press LLC, 1997.

27. Lancia M, Conforti F, Aleffi M, et al. The Use of Leptodyctium riparium (Hedw.) Warnst in the Estimation of Minimum Postmortem Interval. J Forensic Sci 2013; 58: 239-242.

28. G1. São Paulo: Globo Comunicação e Participações S.A.; Updated in 11 March 2013; Accessed in August $6^{\text {th }}$ of 2018. Entenda o caso Mércia Nakashima. Avaliable from: http://g1.globo.com/sao-paulo/noticia/2013/03/entenda-o-caso-mercia-nakashima.html.

29. Carneiro NPM, Torgan LC, Vaz M, et al. Diatoms in lung tissue: first investigation in Brazil in proving death by drowning. Rev Bras Crim 2017; 6: 13-16.

30. Gonçalves AB, Souza JS, Da Silva GG, et al. Feature extraction and machine learning for the classification of Brazilian Savannah pollen grains. PLoS One; 11. Epub ahead of print 2016. DOI: 10.1371/journal.pone.0157044.

31. Miranda T. Brasília: Agência Câmara Notícias; updated on November $24^{\text {th }}$ of 2014; Accessed on August $06^{\text {th }}$ 2018. Comissão aprova desvinculação da perícia criminal da PF, PM e Polícia Civil. Available from: http://www2.camara.leg.br/camaranoticias/noticias/SEGURANCA/478252COMISSAO-APROVA-DESVINCULACAO-DA-PERICIA-CRIMINAL-DA-PF,-PM-EPOLICIA-CIVIL.html

32. Adams-Groom B. Frequency and abundance of pollen taxa in crime case samples from the United Kingdom. Grana 2014; 0: 1-10.

33. Chandra R, Sharma V. Forensic botany: an emerging discipline of plant sciences. Indian Bot Blog-o-Journal 2014; $2-8$.

34. Boi M. Pollen attachment in common materials. Aerobiologia (Bologna) 2015; 31: 261-270.

35. Margiotta G, Bacaro G, Carnevali E, et al. Forensic botany as a useful tool in the crime scene: Report of a case. J Forensic Leg Med 2015; 34: 24-28.

36. Ferri G, Corradini B, Ferrari F, et al. Forensic botany II, DNA barcode for land plants: Which markers after the international agreement? Forensic Sci Int Genet 2015; 15: 131-136. 


\section{Erratum}

In the Article "Botanical Knowledge in the Law Enforcement: a Preliminary Approach Towards its Potential Use in Brazilian Criminal Caseworks" with Running title: "Botany in the Brazilian Law

Enforcement", DOI number: http://dx.doi.org/10.1590/1678-4324-2018160442, published in the journal Brazilian Archives of Biology and Technology, vol. 61, page 1.

That read:

Thales Leandro ${ }^{2}$.

Read:

Thales D. Leandro 